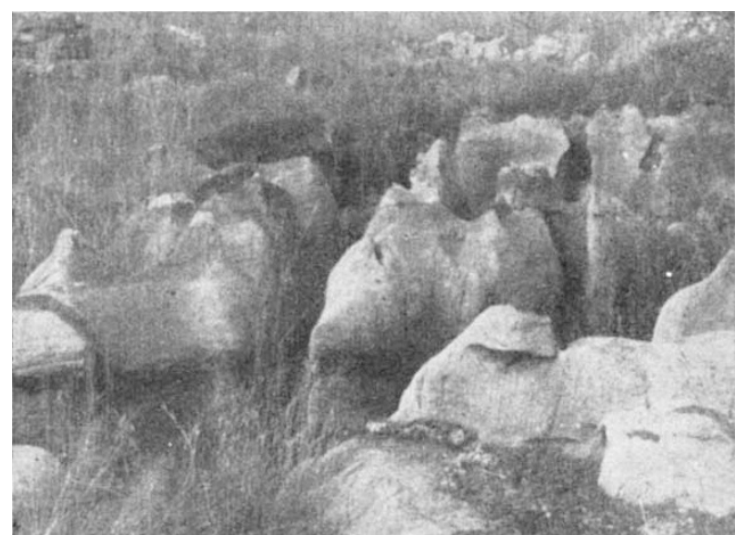

Typical rock structure just below the soils of the Dolomitic limestones. The joints have been opened up by solution and water is now confined to a channel, thus builds up a greater head than if distributed evenly lateraliy and hence feeds to the underground reservoirs. To reconstruct this in a lysimeter or even simulate it in an approximate manner would be very difficult if not impossible. Vast areas of the dolomite present this structure under a thin soil cover

the western extension of the Witwatersrand lends itself to the same experiment. Now the dolomite covers a very great area in South Africa and, owing to the fact that the rock develops very large and extensive solution channels and underground caves? lysimeter experiments of the order of a third of an acre or less (unless they take into account such efficient media for rapidly leading water underground) would give figures that are far too low for the infiltration to the dolomitic limestones.

The South African landscape from the Western Province through the Northern Cape, Free State and the Transvaal into Southern Rhodesia is characterized by closed drainage areas or pans. These pans collect appreciable volumes of water and should act as efficient structures for forcing water underground. However, the fact that most of them contain greater quantities of salts in solution than rivers in the same areas suggests that underground drainage is not a rapid matter, and it is possible that from salinity studies the infiltration to underground could be evaluated. The pans occur over many geological formations and all over South Africa, and it means that results would be of wide application.

Studies of several dams show that the infiltration to underground varies a great deal. In some cases there is an undoubted flow to voids in rocks deeper down; but in others there is a gain from a source which can only be underground water issuing from springs. Boreholes drilled along the edges of dams, although well below the water-level and only a short distance (less than 1,000 ft.), gave such small yields (less than 20 gall. per hr.) that lateral flow from the dam could not be great. Many of our dams, for example, Haartebeestpoort Dam, are built in fault liness, so that ample and permanent supplies of underground water occur on the downstream side.

It appears that, if the elements of the hydrological balance are to be determined in South Africa, the mines of the eastern and western Witwatersrand, coal mines of the Witbank area and the dams and pans of South Africa can give a great quantity of data on underground infiltration, and that such data may be far more generally applicable than lysimeter experiments- of course, only so far as the infiltration to underground is concerned. It is an unfortunate circumstance that in the case of the Orange Free
State gold mines the presence in certain areas of artesian water in the sediments of the Ventersdorp System (water derived probably from the Basutoland Highlands) will prevent the pumpage from those mines being useful in the evaluation of underground recharge in that area.

The Okavango Delta in the northern portion of Bechuanaland could be used to great advantage ${ }^{9}$. Presenting probably a very close approach to a free water surface, evaporimeters plus flow measurements of this river could give a valuable guide to the amounts of water that are fed to underground, and hence of the underground waters of the southern Kalahari and parts of South-West Africa. This would be invaluable in the development of Southern Bechuanaland.

With anxiety being felt of the lasting qualities of our underground waters, it is remarkable that, in the low rainfall areas of the Karroo, boreholes and springs of great yield are found, for example, the flowing springs of Cradock and Aliwal North. West of De Aar in areas of rainfall less than 12 inches, fresh and saline boreholes of 2,000-8,000 gall. per $\mathrm{hr}$. occur within close proximity. In these areas surface limestone and extensive sand stretches facilitate infiltration to underground, and hence a high proportion of the rainfall is made available for subsurface flow. While in high-rainfall areas probably only 3 per cent of the total precipitation (say, more than 24 inches per annum) goes to underground, in these areas 60 per cent of the 12 inches precipitation may rapidly filter to the subterranean storage and flow.

Nature, 164, 805 (1949).

"Foster, E. E., "Rainfall and Run-off"' (Macmillan, 1948).

${ }^{3}$ Many papers in Trans. Amer. Geophys. Union, 1942 onwards. ${ }^{4}$ Sci. Bull. Dep. Agric. S. Africa, No. 288.

' King, L. C., Proc. Geol, Soc. S. Africa, 50, 23 (1948).

- Geol. Surv. S. Africa, Explanation Sheet No. 52 (Johannesburg).

'King, L. C., "South African Scenery" (Oliver and Boyd, 1942).

${ }^{8}$ du Toit, A. L., "Geology of South Africa" (Oliver and Boyd, 1939). ${ }^{\circ}$ Geogr. J.. 113, 62 (1949).

\section{BONE AND TOOTH SOCIETY}

A NEW society has recently been formed which A has the object of providing a discussion ground for those interested mainly, but not exclusively, in fundamental laboratory investigations in bones and teeth. At its first meeting on March 24, it was decided to hold quarterly meetings at which there would be symposia on various aspects of bones and teeth, and there would also be meetings for casual communications where there would be opportunity for discussion by a more specialized audience than might be met with at other scientific society meetings having a more general interest.

An interim committee to look after the Society's interests in various branches, during its formative stage, was elected as follows: $\mathrm{Mr}$. Ivor Kramer, representing dental interests, Dr. C. H. Lack, clinical, Dr. J. J. Pritchard, anatomical, Dr. H. J. Rogers, biochemical, and Dr. H. A. Sissons, histological. Dr. T. F. Dixon, Institute of Orthopædics, Royal National Orthopædic Hospital, 234 Great Portland Street, London, W.1, was elected secretary.

The Society had its first scientific meeting at the Institute of Orthopædics, 234 Great Portland Street, London, W.1, on June 6. This took the form of a symposium on bone structure at which Prof. W. D. Newcomb took the chair. Dr. H. B. Fell discussed the origin and developmental mechanics of the 
embryonic skeleton in warm-blooded animals, and described experiments relating to the origin of chondrogenic and osteogenic tissue in the early embryo, the capacity of embryonic skeletal tissue for regeneration and regulation and the relative import. ance of intrinsic and extrinsic factors in the gross anatomical development of the skeleton. Dr. H. A. Sissons gave an account of the microscopic structure of various types of bone, as seen in the mature skeleton and in embryonic development. He outlined the cellular processes concerned in endochondral and membrane bone formation, and discussed lamellar bone, non-lamellar bone, and osteoid tissue from the histological point of view. Dr. J. J. Pritchard described the evolution of bone structure. He gave a brief assessment of comparative, embryological and palæontological evidence, and referred to the earliest appearance of bone in the geological record. $\mathrm{He}$ discussed the question whether bone or cartilage appeared first in evolution, and the possibility of their simultaneous origin in view of the close ties between the two tissues. $\mathrm{He}_{\theta}$ also described the possible derivation of endochondral bone from membrane bone and the evolution of different types of bony structure culminating in the plastic Haversian systems of large mammals (and large extinct reptiles) with special emphasis on vascular patterns. Dr. T. F. Dixon showed how wide fluctuations in inorganic composition of bone occur under the influence of a variety of conditions; for example, as might be expected from the histological structure, in the same animal there are variations from one bone to another and in different parts of one bone. Dietary variations produce changes in composition and so on. From chemical and such physical examinations as $\mathbf{X}$-ray diffraction patterns and differential solubility measurements, the mode of combination of the inorganic elements can be elucidated. There is still, however, disagreement as to the precise molecular composition. Dr. H. J. Rogers described experiments on the protein and mucopolysaccharide components of the organic matrix of bone, and gave an indication of the identity of the sugars present in the latter.

The Society proposes to have a full programme this winter ; the next meeting will probably be held at the Eastman Dental Clinic, Gray's Inn Road, London, W.C.I, on October 3, when a symposium on "Tooth Structure" will be held.

\section{MANAGEMENT AND WORKERS}

A $T$ their annual conference at Buxton in April A 1950, members of the National Institute of Industrial Psychology pooled their theories and experience to formulate an ideal personnel policy for an industrial organisation. To give the proceedings greater reality, the organisers presented the conference with a detailed description of a hypothetical company about to begin production of a nutritious food-stuff.

Before splitting into five committees, the conference was given some general suggestions by Sir Patrick Hamilton, chairman of Henry Simon, Ltd., and Mr. D. S. A. E. Jessop, personnel director of the Brush Electrical Engineering Co. Sir Patrick thought that the schemes adopted should be capable of modification as the organisation developed and issued a warning against allowing concentration on modern techniques to obscure such principles as honesty, sincerity, fairness and approachability. Mr. Jessop said success would depend largely upon the employees' understanding of the firm's overall working, of its objectives and of their enthusiasm for the venture. The spread of knowledge of what was going on, the possibility of everyone having his suggestions or criticisms heard or acted upon if valid, was what he understood by joint consultation and control, and not the mere division of managerial responsibility among a committee. Effective co-operation depended upon mutual confidence and on assured security in return for a job well done.

The first committee to report back to the plenary session suggested selection methods for appointments to supervisory and management jobs, which would generally place employees in jobs in which they would succeed and find satisfaction. The training committee decided to arrange not only for appropriate training for every grade in techniques, processes and methods of work which would be new to them, but also for a general course on the firm's organisation and production. This would show how each individual or group contributed to the whole.

Another committee dealing with methods of work and environment set before itself the question of maximum output with the minimum of strain. It considered diverse ways of ensuring the cleanliness desirable in a food factory, the best hours of work for a labour force to be composed mainly of women, the prevention of noise, pleasantness of surroundings and general welfare.

A further committee was concerned to see that management direction should be disseminated quickly and accurately through the works and that those in authority should know what was happening below and deal quickly with suggestions of dissatisfaction. They recommended verbal reports to employees on management problems, policy and financial matters, close co-operation and exchange of information between foremen, shop-stewards and between one individual and his immediate subordinate as well as the usual mothods of spreading information.

The only committee to show a serious difference of opinion was that concermed with methods of payment. The majority of its members wanted generous weekly time-rates and the others some form of payment by results. All were agreed that wage-rates should be based on work measurement and some form of job evaluation and that a pension scheme and ultimately a profit-sharing scheme should be introduced. The majority believed that maximum output could be achieved by good supervision and encouraging a good team spirit; the minority that individual incentives are necessary in an imperfect world.

The final speaker was Mr. Giles Howard, of Hayward-Tyler and Co., Ltd., who said he would delegate responsibility within the firm and would see that there would be no over-ruling from above. But though responsibility was granted from above, they must remember that authority came from below. The firm's policy would be wise not clever and based on Christian ethics which were not incompatible with efficiency.

Summing up, General Sir Ronald Adam, chairman of the Institute, said that successful methods of selection using job analysis could be put into operation in industry now, as could efficient training for supervisory posts. Good methods of disseminating knowledge throughout a firm existed and, given the right attitude, could be successful. He was in favour of selection methods being applied to rank and file jobs. 